\title{
Circulating cell adhesion molecules in bronchial lavage and serum in COPD patients with chronic bronchitis
}

\author{
G.C. Riise*, S. Larsson*, C-G. Löfdahl*, B.A. Andersson**
}

Circulating cell adhesion molecules in bronchial lavage and serum in COPD patients with chronic bronchitis. G.C. Riise, S. Larsson, C-G. Löfdahl, B.A. Andersson. CERS Journals Ltd 1994.

ABSTRACT: The initial phase of inflammation in bronchial asthma appears to be triggered by the expression of leucocyte-endothelial adhesion molecules on endothelial cell surfaces. Cell adhesion molecules (CAMs) cause adhesion of leucocytes to the endothelium prior to their subsequent extravasation into inflamed tissue. We wanted to determine whether circulating intercellular adhesion molecule-1 (cICAM-1) and circulating E-selectin (cE-selectin) could be detected in bronchial lavage fluid and serum in patients with stable chronic obstructive pulmonary disease (COPD) and chronic bronchitis.

Bronchoscopy and small volume bronchial lavage was performed in 19 patients with COPD and chronic bronchitis and in 13 control subjects.

We found increased mean levels of cICAM-1 both in serum $\left(481 \mu \mathrm{g} \cdot l^{-1}\right)$ and in bronchial lavage $\left(24 \mu \mathrm{g} \cdot l^{-1}\right)$ in the COPD patients as compared to the controls (321 $\mu \mathrm{g} \cdot l^{-1}$ in serum, $15 \mu \mathrm{g} \cdot l^{-1}$ in lavage). We also found higher mean levels of $\mathrm{cE}$-selectin in serum from the COPD patients $\left(86 \mu \mathrm{g} \cdot l^{-1}\right)$ compared to controls $\left(50 \mu \mathrm{g} \cdot l^{-1}\right)$. The serum levels of cE-selectin correlated significantly with lung function measured as forced expiratory volume in one second $\left(\mathrm{FEV}_{1}\right)$ in percentage of predicted. Patients with significant intrabronchial bacterial colonization had increased levels of serum cE-selectin.

Our results indicate that cCAMs may reflect an upregulation of CAMs on endothelial and epithelial airway cells in COPD.

Eur Respir J., 1994, 7, 1673-1677.
*Dept of Pulmonary Medicine, Renströmska Hospital, Göteborg, Sweden. **Dept of Clinical Immunology, Göteborg University, Sweden.

Correspondence: G.C. Riise

Dept of Pulmonary Medicine Renströmska Hospital

P.O.B. 17301

S-402 64 Gothenburg

Sweden

Keywords: Bronchial lavage cell adhesion molecules

chronic bronchitis

chronic obstructive pulmonary disease

Received: May 61994

Accepted for publication July 31994
The initial phase of inflammation in bronchial asthma and chronic bronchitis appears to be triggered by the expression of leucocyte-endothelial adhesion molecules on endothelial cell surfaces [1]. These cell adhesion molecules (CAMs) serve as ligands for leucocyte cell receptors, mediating the adhesion of leucocytes to the endothelium prior to their subsequent extravasation into inflamed tissue [2]. E-selectin (endothelial-leucocyte adhesion molecule-1 (ELAM-1)), a single-chain glycoprotein, is thought to underlie the initial leucocyte rolling on the vessel wall in areas of inflammation [3]. Intercellular adhesion molecule-1 (ICAM-1) and vascular adhesion molecule-1 (VCAM-1) are related molecules belonging to the immunoglobulin supergene family [1]. All three CAMs have been associated with the mucosal inflammation seen in asthma and allergic rhinitis [4, 5], and in chronic obstructive pulmonary disease (COPD) with chronic bronchitis [6].

Recently, it has been possible to measure circulating forms of CAMs (cCAMs) in body fluids [7]. It is likely that cCAMs originate from adhesion molecules expressed on activated cells [8], and that their presence may reflect inflammatory activity. Levels of circulating ICAM-1 (cICAM-1), cE-selectin and cVCAM-1 have been discovered in bronchoalveolar lavage fluid from patients with interstitial lung disease [9], and serum in active tuberculosis [10]. In asthmatics, increased levels of cICAM-1 and cE-selectin were found in serum of patients with acute asthma $[11,12]$. The levels remained unchanged in spite of high dose corticosteroid treatment for 28 days, and these cCAMs could possibly be indirect markers for acute airways inflammation in asthma [12].

In the present study, we investigated the levels of cICAM-1 and cE-selectin in small volume bronchial lavage and serum in COPD patients with stable chronic bronchitis as compared with healthy controls. We tried to relate the levels of cCAMs to the severity of the disease.

\section{Patients and methods}

The control group consisted of 13 healthy lifelong nonsmoking volunteers, with normal spirometry and no signs of infectious respiratory disease during the past 4 weeks. The 19 patients had COPD (defined as a forced expiratory volume in one second $\left(\mathrm{FEV}_{1}\right)$ less than $80 \%$ of predicted and a reversibility less than $10 \%$ of 
baseline $\mathrm{FEV}_{1}$ on $\beta_{2}$-agonists) and chronic bronchitis. All of the patients were current smokers with productive daily cough for at least three consecutive months each year during the past $2 \mathrm{yrs}$, and without signs of infectious respiratory disease for the past 4 weeks.

Of the 19 patients, eight used oral $\mathrm{N}$-acetylcysteine regularly (200 $\mathrm{mg}$ at least twice daily) and four used inhalation steroid medication regularly. The duration of the bronchitis symptoms in the patient group varied from 5 to 24 yrs, with a mean of 14.5 yrs. The patients were significantly older than the controls, and had a significantly lower lung function measured as $\mathrm{FEV}_{1}$ in percentage of predicted (table 1).

Criteria for exclusion were abnormal chest X-ray, bronchial hypersecretion caused by factors other than cigarette smoking, a history of asthma or reversibility $>10 \%$ on $\beta_{2}$-agonists, and, for safety reasons, an $\mathrm{FEV}_{1}$ less than $50 \%$ predicted or age more than 70 yrs. Ventilatory lung function $\left(\mathrm{FEV}_{1}\right)$ was measured with a Bernstein spirometer or Vitalograph in a standardized manner, according to the directions of the European Community for Coal and Steel [13].

The study design was approved by the Ethics Committee of the University of Göteborg, and the volunteers gave their consent after both written and oral information.

\section{Fibreoptic bronchoscopy}

Premedication was given with haloperidol $5 \mathrm{mg}$ orally followed by $0.5-1 \mathrm{ml}$ morphine-scopolamine i.m. Five $\mathrm{ml} 1 \%$ tetracaine without preservative was nebulized with a pressurized nebulizer (Plug-in inhalator, Aiolos
Systems, Karlstad, Sweden) and inhaled in an upright position for local anaesthesia. All bronchoscopies were performed transorally by one of two experienced bronchoscopists, and with the patient in the supine position. Several models of Olympus flexible fibreoptic bronchoscopes were used.

Bacterial and viral samples were taken during the bronchoscopy according to WIMBERLEY et al. [14], using inhalation anaesthesia and a telescoping double-catheter protected specimen brush (Microvasive catheter no. 1650). The detailed results have been published previously [15]. In brief, all viral and bacterial samples were taken during an infection-free period, and quantitative bacterial cultures and virus isolations were performed. Significantly positive bacterial cultures were found in six of the 19 COPD patients, and in none of the 13 controls. No viruses were isolated.

\section{Collection of samples}

All samples were collected between 8.30 and 10 a.m. Five millilitres of serum was obtained after centrifugation of a $10 \mathrm{ml}$ venous blood sample, and frozen at $-20^{\circ} \mathrm{C}$ for later analysis. Small volume bronchial lavage was collected by installing $5 \mathrm{ml}$ sterile phosphate-buffered saline (PBS) with the bronchoscope in an unwedged position in segment three in the right upper lobe. The fluid was immediately aspirated, collected in a sterile container and transported to the laboratory where it was frozen at $-20^{\circ} \mathrm{C}$. Before analysis, the fluid was thawed and centrifuged at $10,000 \times \mathrm{g}$ for $15 \mathrm{~min}$. The supernatant was used for analysis as described previously [16].

Table 1. - Clinical data of healthy controls $(n=13)$ and patients with COPD and chronic bronchitis $(n=19)$

\begin{tabular}{|c|c|c|c|c|c|c|c|c|c|c|}
\hline $\operatorname{Sex}$ & $\begin{array}{r}\text { Age } \\
\text { yrs }\end{array}$ & $\begin{array}{l}\mathrm{FEV}_{1} \\
\% \text { pred }\end{array}$ & $\begin{array}{l}\text { Pack- } \\
\text { years }\end{array}$ & Medication & Sex & $\begin{array}{l}\text { Age } \\
\text { yrs }\end{array}$ & $\begin{array}{l}\mathrm{FEV}_{1} \\
\% \text { pred }\end{array}$ & $\begin{array}{l}\text { Pack- } \\
\text { years }\end{array}$ & $\begin{array}{c}\text { Bronchitis } \\
\text { yrs }\end{array}$ & $\begin{array}{l}\text { Regular } \\
\text { medication }\end{array}$ \\
\hline \multicolumn{5}{|c|}{ Controls } & \multicolumn{6}{|c|}{ COPD and chronic bronchitis } \\
\hline M & 33 & 106 & 0 & 0 & M & 64 & 73 & 40 & 20 & 0 \\
\hline $\mathrm{F}$ & 46 & 98 & 0 & 0 & M & 68 & 55 & 50 & 24 & IS \\
\hline $\mathrm{F}$ & 38 & 100 & 0 & 0 & M & 70 & 55 & 45 & 21 & NAC \\
\hline $\mathrm{F}$ & 47 & 104 & 0 & 0 & M & 60 & 66 & 90 & 22 & NAC \\
\hline $\mathrm{F}$ & 26 & 110 & 0 & 0 & $\mathrm{~F}$ & 57 & 73 & 30 & 11 & NAC \\
\hline M & 34 & 100 & 0 & 0 & M & 68 & 57 & 55 & 8 & NAC \\
\hline M & 47 & 102 & 0 & 0 & M & 57 & 51 & 40 & 9 & NAC \\
\hline $\mathrm{F}$ & 66 & 96 & 0 & 0 & M & 66 & 50 & 40 & 5 & 0 \\
\hline M & 55 & 98 & 0 & 0 & $\mathrm{~F}$ & 51 & 50 & 52 & 12 & NAC \\
\hline $\mathrm{F}$ & 37 & 102 & 0 & 0 & M & 47 & 67 & 60 & 5 & 0 \\
\hline $\mathrm{F}$ & 51 & 100 & 0 & 0 & M & 56 & 61 & 26 & 22 & IS \\
\hline $\mathrm{F}$ & 59 & 95 & 0 & 0 & $\mathrm{~F}$ & 38 & 75 & 19 & 13 & 0 \\
\hline $\mathrm{F}$ & 66 & 101 & 0 & 0 & M & 44 & 70 & 45 & 16 & 0 \\
\hline \multirow{6}{*}{ Mean } & \multirow{6}{*}{47} & \multirow{6}{*}{101} & \multirow{6}{*}{0} & \multirow[t]{6}{*}{ - } & M & 60 & 71 & 20 & 16 & 0 \\
\hline & & & & & $\mathrm{F}$ & 58 & 67 & 45 & 15 & 0 \\
\hline & & & & & F & 59 & 67 & 65 & 10 & IS \\
\hline & & & & & $\mathrm{F}$ & 49 & 50 & 30 & 8 & NAC \\
\hline & & & & & M & 60 & 70 & 45 & 20 & NAC \\
\hline & & & & & Mean & 57 & 63 & 44 & 14.5 & - \\
\hline
\end{tabular}

COPD: chronic obstructive pulmonary disease; M: male; F: female; $\mathrm{FEV}_{1}$ : forced expiratory volume in one second; IS: inhaled steroids; NAC: N-acetylcysteine. 


\section{Analysis of cCAMs}

Soluble ICAM-1 and soluble E-selectin were determined as single determinations using commercial assays (R\&D Systems Europe Ltd, Abingdon, Oxon, UK). The serum samples were diluted 1:20 and the small volume bronchial lavage samples 1:4 in sample diluent. The assay was an enzyme-linked immunosorbent assay (ELISA) using one unconjugated and one conjugate monoclonal antibody directed to different determinants on the antigen (i.e. the compound to be analysed). The unconjugated antibody was coated onto the walls of microtitre wells. Any antigen present formed a bridge between the unconjugated and the conjugated antibody. The assay was standardized against a purified soluble form of recombinant ICAM-1 or E-selectin. By analysing standards of known concentration coincident with samples a curve of signal versus concentration could be constructed, and the concentration of unknowns determined.
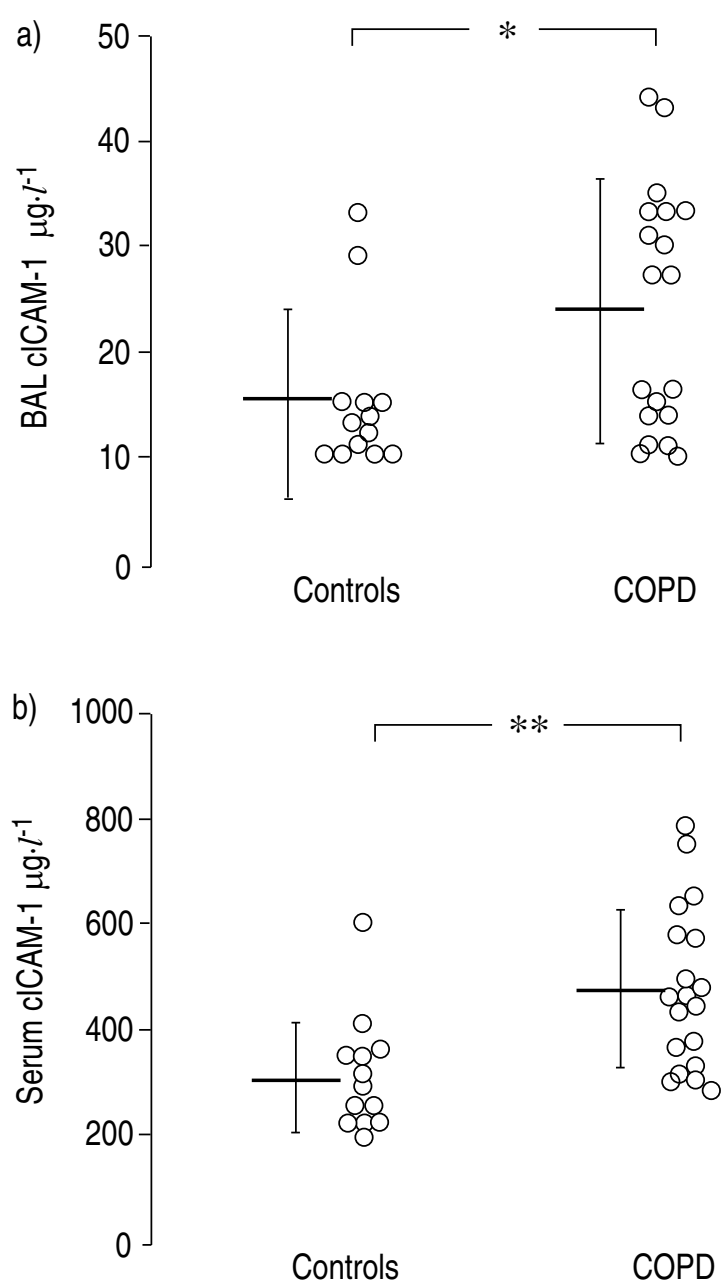

Fig. 1. - Circulating intercellular adhesion molecule-1 (cICAM-1) in: a) bronchial lavage (BAL); and b) serum of healthy controls $(n=13)$ and of patients with COPD and chronic bronchitis $(n=19)$. Bars represent mean \pm SD. COPD: chronic obstructive pulmonary disease. Significant differences from controls. *: $\mathrm{p}<0.05$; **: $\mathrm{p}<0.01$ (Mann-Whitney Utest).

\section{Statistical evaluation}

Mann-Whitney U-test was used for the comparison of the distribution of levels of cCAMs between groups of subjects. Spearman's rank correlation test was used to examine possible associations between serum and bronchial lavage levels of cCAMs, and clinical parameters. Values of $\mathrm{p}<0.05$ were considered statistically significant.

\section{Results}

The patients with COPD and chronic bronchitis had significantly higher mean levels of cICAM-1 in serum $(\mathrm{p}<0.01)$ and in small volume bronchial lavage $(\mathrm{p}<0.05)$ as compared to the controls (fig. 1).

The mean levels of cE-selectin in serum were significantly higher in the patients $(\mathrm{p}<0.001)$ as compared to the controls. The mean levels of cE-selectin in bronchial lavage, however, were all low and did not differ between the two groups of subjects (fig. 2). In addition, serum
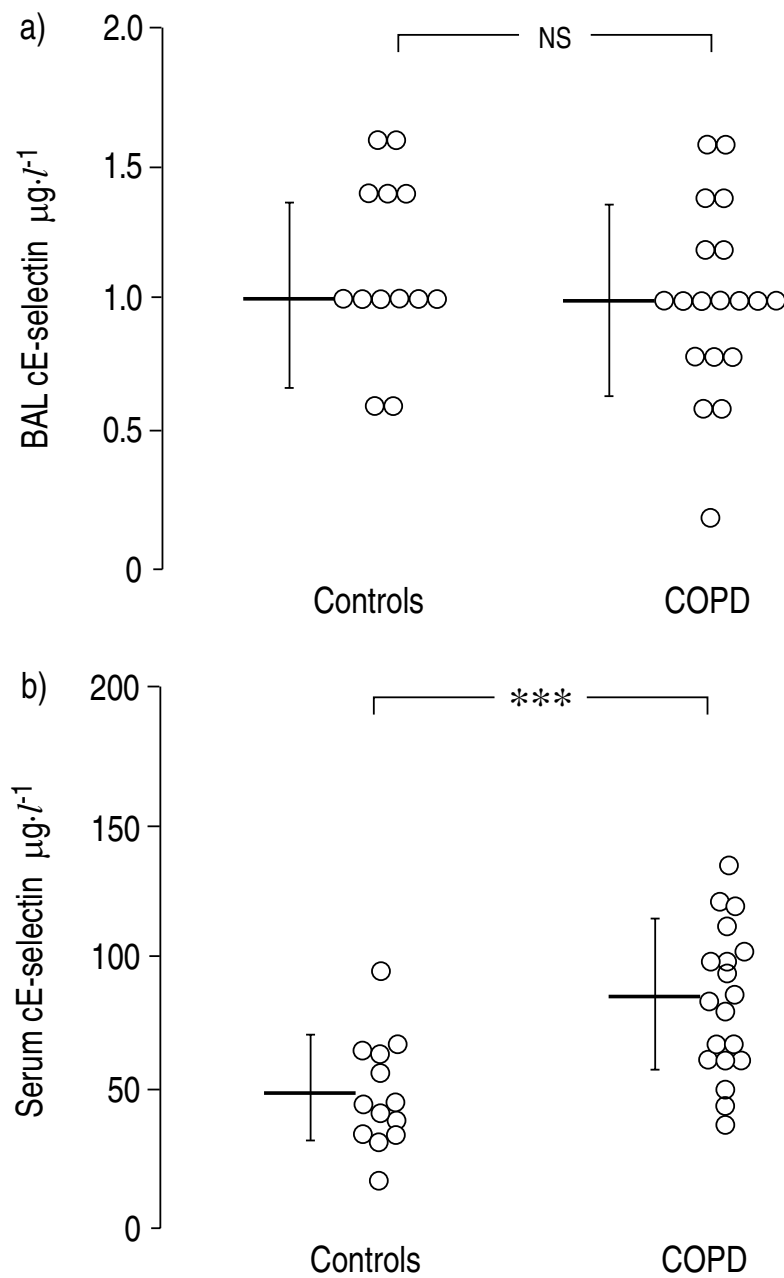

Fig 2. - Circulating endothelial-leucocyte adhesion molecule (cEselectin) in: a) bronchial lavage (BAL); and b) serum in healthy controls $(n=13)$ and in patients with COPD and chronic bronchitis. Bars represent mean \pm sD. COPD: chronic obstructive pulmonary disease. Significant differences from controls: NS: nonsignificant; ***: $\mathrm{p}<0.001$ (MannWhitney U-test). 
Table 2. - Levels of circulating cell adhesion molecules in serum and bronchial lavage from patients with COPD and chronic bronchitis with and without significant intrabronchial bacterial growth

\begin{tabular}{|c|c|c|c|c|c|c|}
\hline \multirow{3}{*}{$\begin{array}{l}\text { With bacterial growth } \\
\text { Without bacterial growth }\end{array}$} & \multirow{2}{*}{$\begin{array}{c}\text { Patients } \\
\text { n }\end{array}$} & \multicolumn{2}{|c|}{$\begin{array}{cc}\text { cICAM-1 } & \mu \mathrm{g} \cdot l^{-1} \\
\text { Serum } & \text { Lavage }\end{array}$} & \multicolumn{3}{|c|}{ cE-selectin $\mu \mathrm{g} \cdot l^{-1}$} \\
\hline & & 497 (154) & $26(15)$ & $107 * *$ & (24) & $1.0(0.6)$ \\
\hline & 12 & 481 (158) & $25 \quad(13)$ & 74 & (22) & $0.9(0.4)$ \\
\hline
\end{tabular}

Data are presented as mean (SD). Significant difference: **: $\mathrm{p}<0.01$ (Mann-Whitney U-test). COPD: chronic obstructive pulmonary disease; cICAM-1: circulating intercellular adhesion molecule-1; cE-selectin): circulating E-selectin.

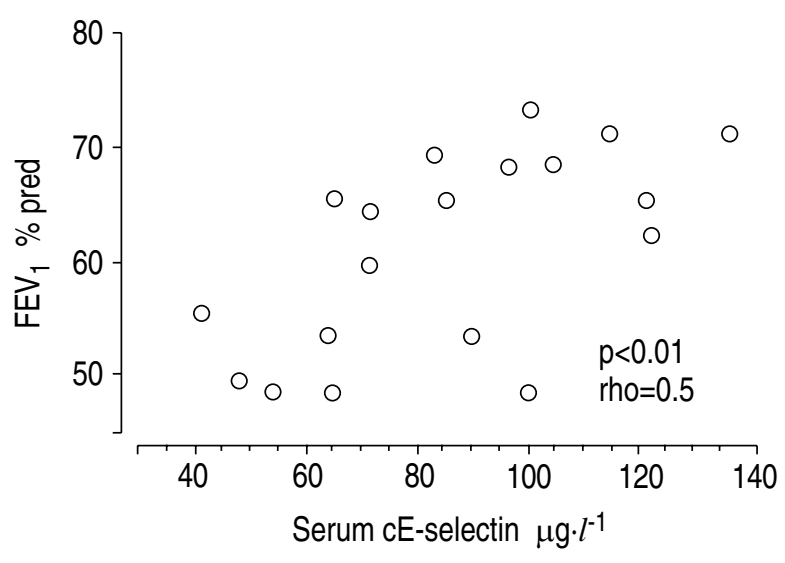

Fig. 3. - Correlation between circulating endothelial-leucocyte adhesion molecule (cE-selectin) in serum and $\mathrm{FEV}_{1}$ in patients with COPD and chronic bronchitis $(n=19)$, (Spearman's rank correlation test). COPD: chronic obstructive pulmonary disease; $\mathrm{FEV}_{1}$ : forced expiratory volume in one second.

cICAM-1 correlated significantly with serum cE-selectin (rho=0.44; $\mathrm{p}<0.01$, Spearman's rank correlation test).

The mean serum levels of cE-selectin in the COPD patients with significant intrabronchial bacterial colonization $(n=6)$ were higher than in the patients without bacterial growth $(n=12),(p<0.01)$. One patient had been excluded due to bacterial contamination during bronchoscopy. Neither the lavage levels of cE-selectin, nor the serum and lavage levels of cICAM-1 differed significantly between the groups (table 2).

In the COPD patients, serum cE-selectin correlated significantly with $\mathrm{FEV}_{1}$ (rho=0.59; $<<0.01$, Spearman's rank correlation test) (fig. 3). No other clinical parameter, e.g. age, smoking habits, airway medication, or duration of bronchitis symptoms correlated with the levels of the CAMs studied.

\section{Discussion}

In the present study we found increased mean levels of cICAM-1 both in serum and in small volume bronchial lavage fluid from patients with COPD and chronic bronchitis as compared to healthy controls. We also observed higher mean serum levels of $\mathrm{cE}$-selectin in the COPD patients as compared to the controls.

To our knowledge, this is the first report of cCAMs both in serum and small volume bronchial lavage fluid from patients with COPD and chronic bronchitis. Interestingly, Di STEFANO et al. [6] recently reported increased immunohistochemical expression of E-selectin on vessels in bronchial biopsies from patients with COPD and chronic bronchitis. In addition, they found increased expression of ICAM-1 on the basal epithelial cells. Our findings of increased levels of the circulating forms of E-selectin in serum and ICAM-1 in bronchial lavage seem to reflect what Di Stefano et al. [6] found in histological preparations. This supports the hypothesis that high levels of circulating CAMs may be associated with an upregulation of CAMs on endothelial and epithelial surfaces in COPD.

In the present study, increasing serum levels of $\mathrm{cE}$ selectin was seen to correlate significantly with increasing lung function measured as $\mathrm{FEV}_{1}$ in percentage of predicted in the COPD patients. This direct positive relationship is difficult to interprete, and it could be a secondary effect due to the airway disease itself. More speculatively, the high levels of cE-selectin in serum could be a sign of a systemic defensive measure directed against the ongoing airway inflammation in COPD. No significant correlation was found for cICAM-1 and FEV . $^{\text {. }}$

The ICAM-1 molecule is known to serve as the main surface receptor for rhinoviruses [17], and to be upregulated on airway epithelial cells by viral infection [18]. It is therefore essential to investigate the possibility of ongoing infection in a study of cell adhesion molecules. Our patients were thoroughly investigated concerning the possibility both of bacterial and viral infection by means of a protected specimen brush, viral isolations and cultures [15], as well as a negative subject history for airway infections four weeks prior to the study. It is, therefore, unlikely that an acute viral infection could have affected our results. However, without using viral polymerase chain reaction techniques, we cannot rule out the possibility of latent chronic viral infection in the COPD patients [19].

As reported previously [15], six COPD patients had a significant intrabronchial bacterial colonization at the time of the study, and they were found to have increased levels of cE-selectin in serum. This is in agreement with earlier reports where E-selectin has been shown to be inducible by bacterial endotoxin, and to mediate adhesion of polymorphonuclear neutrophils [20]. Our finding emphasizes the importance of simultaneous investigation of the intrabronchial bacterial flora when studying CAMs in patients with chronic bronchitis.

To obtain samples predominantly reflecting the status of the bronchial epithelium, it has been shown that small volume lavage of the large airways is of more value than 
the traditional bronchoalveolar lavage with its admixture of alveolar and serum components [21, 22]. The lack of correlations between the serum and bronchial lavage levels of the cCAMs in the present study do not support the idea that the measured cCAM lavage levels are due to passive leakage of the molecules from serum into the airways.

Our findings of increased levels of the circulating forms of E-selectin in serum and ICAM-1 in bronchial lavage support the hypothesis that high levels of circulating CAMs may be associated with an upregulation of CAMs on endothelial and epithelial surfaces in COPD. It is possible that these CAMs are involved in the pathogenesis of COPD. However, the individual cCAM values of the controls and COPD patients in our study partly overlap, which makes the interpretation of a single sample unsuitable for diagnostic purposes.

Acknowledgements: The authors are grateful for the generous support from the Swedish Heart and Lung Foundation that made this study possible.

\section{References}

1. Pilewski JM, Albelda SM. Adhesion molecules in the lung: an overview. Am Rev Respir Dis 1993; 148: S31-S37.

2. Montefort S, Holgate ST, Howarth PH. Leucocyteendothelial adhesion molecules and their role in bronchial asthma and allergic rhinitis. Eur Respir J 1993; 6: 1044-1054.

3. Lawrence MB, Springer TA. Leukocytes roll on a selectin at physiologic flow rates: distinction from and prerequisite for adhesion through integrins. Cell 1991; 65: 859-873.

4. Wegner CD, Gundel RH, Reilly P, Haynes N, Gordon Letts L, Rothlein R. ICAM-1 in the pathogenesis of asthma. Science 1990; 247: 416-418.

5. Montefort S, Feather IH, Wilson SJ, Haskard DO, Lee TH, Holgate ST, Howarth PH. The expression of leucocyteendothelial adhesion molecules is increased in perennial allergic rhinitis. Am J Respir Cell Mol Biol 1992; 7: 393-398.

6. Di Stefano A, Maestrelli P, Roggeri A, et al. Upregulation of adhesion molecules in the bronchial mucosa of subjects with chronic obstructive bronchitis. Am J Respir Crit Care Med 1994; 149: 803-810.

7. Seth R, Raymond FD, Makgoba MW. Circulating ICAM1 isoforms: diagnostic prospects for inflammatory and immune disorders. Lancet 1991; 338: 83-84.

8. Rothlein R, Mainolfi EA, Czajkowski M, Marlin SD. A form of circulating ICAM-1 in human serum. J Immunol 1991; 147: 3788-3793.
9. du Bois RM, Hellewell PG, Hemingway I, Gearing AJ. Soluble cell adhesion molecules ICAM-1, ELAM-1 and VCAM-1 are present in epithelial lining fluid in patients with interstitial lung disease. Am Rev Respir Dis 1992; 145: A190.

10. Lai CK, Wong $\mathrm{KC}$, Chan $\mathrm{CH}$, et al. Circulating adhesion molecules in tuberculosis. Clin Exp Immunol 1993; 94: 522-526.

11. Hashimoto S, Imai K, Kobayashi T, et al. Elevated levels of soluble ICAM-1 in sera from patients with bronchial asthma. Allergy 1993; 48: 370-372.

12. Montefort S, Lai CK, Kapahi P, Haskard DO, Holgate ST, Howarth PH. Circulating adhesion molecules in asthma. Thorax 1992; 47: 852 (A).

13. Quanjer P, (ed). Standardized lung function testing. Report Working Party Standardization of Lung Function Tests. European Community for Coal and Steel. Bull Eur Physiopathol Respir 1983; 19 (Suppl. 5): 195.

14. Wimberley N, Faling LJ, Bartlett JG. A fiberoptic bronchoscopy technique to obtain uncontaminated lower airway secretions for bacterial culture. Am Rev Respir Dis 1979; 119: 337-343.

15. Riise GC, Larsson S, Larsson P, Jeansson S, Andersson BA. The intrabronchial microbial flora in chronic bronchitis patients. A target for $\mathrm{N}$-acetylcysteine therapy? Eur Respir J 1994; 7: 94-101.

16. Bousqet J, Chanez P, Lacoste JY, et al. Eosinophilic inflammation in asthma. $N$ Engl J Med 1990; 323: 1033-1039.

17. Greve JM, Davis G, Meyer AM, et al. The major human rhinovirus receptor is ICAM-1. Cell 1989; 56: 839847.

18. Tosi M, Stark J, Hamedani A, Wayne Smith C, Gruenerts D, Huang Y. Intercellular adhesion molecule-1 (ICAM1) dependent and ICAM-1 independent adhesive interactions between polymorphonuclear leukocytes and human airway epithelial cells infected with parainfluenza virus type 2. J Immunol 1992; 149: 3345-3349.

19. Matsuse T, Hayashi S, Kuwano K, Keunecke H, Jefferies W, Hogg J. Latent adenoviral infection in the pathogenesis of chronic airway obstruction. Am Rev Respir Dis 1992; 146: 177-184.

20. Luscinskas FW, Brock AF, Arnaout MA, Gimbrone MA. ELAM-1 dependent and leucocyte (CD11/CD18)-dependent mechanisms contribute to PMN adhesion to cytokine activated human vascular endothelium. J Immunol 1989; 142: 2257-2263.

21. Lam S, Leriche JC, Kijek K, Phillips D. Effect of bronchial lavage volume on cellular and protein recovery. Chest 1985; 88: 856-859.

22. Rennard SI, Ghafouri MO, Thompson AB, et al. Fractional processing of sequential bronchoalveolar lavage to separate bronchial and alveolar samples. Am Rev Respir Dis 1990; 141: 208-217. 